\title{
An Ethos of Sharing in the Maker Community
}

\author{
Ms. Christina Hobson Foster, Arizona State University \\ Dr. Micah Lande, Arizona State University, Polytechnic campus
}

Dr. Micah Lande teaches human-centered design innovation at Arizona State University and researches how engineers learn and apply a design process to their work. He is an assistant professor in the Department of Engineering on Arizona State University's Polytechnic campus. Dr. Lande is currently the PI for an NSF funded project investigating the educational pathways of adult Makers and is a co-PI on another NSF funded project on Young Makers. Dr. Lande received his B.S in Engineering (Product Design), M.A. in Education (Learning, Design and Technology) and Ph.D. in Mechanical Engineering (Design) from Stanford University's Center for Design Research.

\section{Dr. Shawn S Jordan, Arizona State University, Polytechnic campus}

Shawn Jordan, Ph.D.is an Assistant Professor in theDepartment of Engineering atArizona State University. He is the PI on three NSF-funded projects: CAREER: Engineering Design Across Navajo Culture, Community, and Society (EEC 1351728), Might Young Makers be the Engineers of the Future?(EEC 1329321), and Broadening the Reach of Engineering through Community Engagement (BRECE)(DUE 1259356). He is also Co-PI on one NSF-funded project: Should Makers be the Engineers of the Future?(EEC 1232772), and is senior personnel on an NSF-funded grant entitled Workshop: I-Corps for Learning (i-Corps-L). He received his Ph.D. in Engineering Education (2010)and M.S./B.S. in Electrical and Computer Engineeringfrom Purdue University, and as a qualitative researcher studies both STEM and informal engineering education. As an educator, he foundedandled a team to two collegiate National Rube Goldberg Machine Contestchampionships, and has co-developed theSTEAMMachines ${ }^{\mathrm{TM}}$ /"Rube Goldbergineering" program over the past 6 years to exposemiddle and high school students to the engineering design process. 
An Ethos of Sharing in the Maker Community

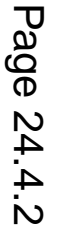




\section{Introduction}

The term ethos is a Greek word meaning "character" and is used to describe the guiding beliefs or ideals that characterize a community ${ }^{1}$. Maker communities are comprised of groups of individuals who share common interests in the tinkering, hacking, re-making, and creating of technical artifacts, done with or without prior expertise ${ }^{2}$. Maker communities are often informal collaborations (doing-it-with-others) between Makers that support and celebrate building and prototyping technical proof-of-concept exploration and ad-hoc product development. The label "Maker" is a self-determined one assigned by affinity or involvement in a Making community. As a modern-day tinkerer and hands-on doer and fashioner of stuff, Makers and their communities share an enthusiasm and appreciation for building and creation.

Individual Makers and Maker groups embark on projects of all sorts, led primarily by their interests and curiosities, informed by their skills or the skills they want to learn. They make creative efforts like fire-breathing robots as performance art, combining contributions from community members with electrical, mechanical and embedded systems know-how ${ }^{3}$ or construct intricate, wooden geometric puzzles $\mathrm{CNC}^{\prime} \mathrm{d}$ from exotic woods commissioned by patrons ${ }^{4}$. They show off their work readily and share their technical recipes with those interested. Done outside the confines of established engineering education curricular activities, Making comes from an imaginative, creative mind-space and is a shareful practice.

Making is defined by a do-it-yourself ideal and is historically rooted in efforts like Popular Mechanics magazine who demystified everyday stuff for hobbyists and the Whole Earth Catalog: Access to Tools ${ }^{5}$ who surveyed everyday tools for the counterculture movement of the 1960s. Additional real-world touchstones are the growth of Radio Shack stores and the 1980s television program MacGyver where the lead character would resolve each episode's predicament by fashioning an escape plan out of found objects ${ }^{6}$. Technology and sharing of information via the Internet has greatly increased the ability for smaller Making communities with shared interests to coalesce and grow. Today, Makers populate Maker spaces and hacker spaces $^{8}$ and use commercial ventures like Tech Shop ${ }^{7}$ and Maker Bench ${ }^{2}$ to gather with other Makers. A significant part of such participation is to benefit from opportunities to continue learn from, teach and mentor other Makers.

Make magazine and the Maker Faire are champions of the Make movement and described as "a central organ of the maker movement" . Founded in 2006 as a quarterly publication, Make magazine presents "DIY Projects, Inspiration, How-tos, Hacks, Mods \& More" ${ }^{2}$. Its pages celebrate the people engaged in Making and is a modern-day equivalent of the Whole Earth Catalog crossing technology with the category of tools covered. Craft and Ambidextrous Journal of Design have been additional efforts to capture the people and processes of crafting and design thinking respectively. Maker Faire has been an outreach effort of Make magazine, convening flagship, multi-day fair events in select cities and supporting smaller, regional one-day events around the country. Serving as the world's largest "show and tell", its credo is to "celebrate arts, crafts, engineering, science projects and the DIY mindset." ${ }^{2}$. The first Maker Faire was in the San Francisco Bay Area in 2006, attracting 100 exhibitors and 40,000 attendees. In 2010, the Bay Area Maker Faire hosted 1,000 makers and had 80,000 in attendance $^{10}$. Maker Faires have been held there since then, with Austin added for 2007 and 2008, and Detroit and New York in 2010 and 2011. 
Makers and Maker groups volunteer to exhibit at Maker Faire festivals. They are assigned a 4' x 10' (or larger) space inside an exhibition hall or an outdoor area to then set up their exhibits and demonstrations. There are also workshops and talks on a main stage as well as special events scheduled throughout the event. For the flagship Maker Faire events, attendees pay a nominal entry fee for a ticket (\$20-28) for admittance on one of the two-day weekend festival. It is a place where Makers come and share what they have made and learned.

\section{Problem Statement}

The purpose of this study is to systematically explore a vein of the Maker ethos: enthusiasm for Making and sharing knowledge and technical artifacts that have been Made. This exploration encompasses surveying how Makers engage in communities of practice and knowledge brokering ${ }^{11}$. Although their work is done outside of structured engineering education, their commitment to collaborating and engagement in the community is something that can be better understood to advantage our teaching in the engineering classroom. This approach aligns with project-based learning as a teaching method in the classroom, a call made in Sheppard's

Educating Engineers: Designing for the Future of the Field ${ }^{12}$. Engaging future engineering students may mean developing curriculum and pedagogy that allows students to apply their knowledge and Make. ABET and the Engineer of 2020 emphasizes that future engineers must be lifelong learners and able to communicate and collaborate with multiple stakeholders ${ }^{13}$. There is opportunity to leverage the Maker experience to better understand collaboration and communication among a group of self-ascribed lifelong learners.

\section{Research Questions}

This study is situated within a larger study that seeks to understand the knowledge, skills, and attributes of Makers that can relate to engineering. The purpose of this larger study is to establish evidence as to how Makers embody specific attributes of the Engineer of 2020 and discover additional attributes that could define the engineer of the future. The study presented within this paper is specifically aimed at understanding how Makers engage in communities of practice. Specifically two research questions guided this study: (1) who do Makers collaborate with during their Making and (2) how do the Makers interact and engage in collective learning at the Maker Faires?

\section{Research Approach}

This study relied upon attending the Maker Faires and interacting with Makers. To identify participants for the study, a participant screening questionnaire was administered to exhibitors at three Maker Faire festivals (the New York Maker Faire 2012, 2013, and the Bay Area Maker Faire 2013). Stratified purposeful sampling was performed to select participants and maximize variation among the participants. The criteria for selecting participants was that they self-identify 
as a Maker and are adults (18 or older). Twenty-one adult Makers participated in this study. Twelve were male; nine were female. The majority of participants identified as being a Maker for over 10 years (11 participants), while the remaining participants identified as being a Maker for 5-10 years ( 7 participants), 1-4 years ( 1 participant), and less than 1 year ( 1 participant). The majority of participants identified as having an engineering-related job/career (16 participants).

Artifact elicitation interviews, based on the method of photo elicitation ${ }^{14}$, were conducted with the 21 participants in front of the their exhibits at the Maker Faire festivals. The artifact elicitation interviews were audio and video-taped for later transcription. The artifact elicitation interview protocol relied on the physical artifact that the Maker created and brought to the festival, and began with asking the participants to describe the artifact and why they brought this artifact to the Maker Faire. Follow-up questions asked the participants to describe their design process, including describing how they collaborated with other individuals. An aim of the interviews was to elicit ways Makers participate in communities of practice. Follow-up critical incident interviews ${ }^{15}$ of approximately one hour each were conducted via Skype with those participants that agreed to participate. These interviews asked the Makers to elaborate upon how they define Making, their educational experiences, and their experiences with Making.

The analysis for this study primarily relied on inductive analysis on the transcribed interviews, whereby emergent themes were identified and labeled using the Nvivo analysis tool and then categorized according to themes. Deductive analysis (fitting data to existing theory) based on relevant theories, including pathways theory, social-cognitive career theory, adult learning theory, identity theory, motivation theory, and retention theory, is the next phase of this study.

\section{Findings}

\section{Who do Makers collaborate with during their Making?}

The Makers in this study reported that they seek to collaborate with other Makers and individuals who have knowledge or expertise related to the Making of the artifact. Often these collaborations are with people with different skills and knowledge (e.g. an engineer working with a craftsperson and a musician) and are a result of participating in formal and informal Making, technical, and art communities. One participant who works as a bioengineer and Makes his own technical devices explains that his latest biofeedback device was a result of a collaboration he did with a friend. "This work is precipitated by some work I did at Burning Man a few years ago on a larger scale project that went on. I was helping a friend out and we were working jointly. This came out of that. It got more refined out of that process." The majority of participants reported that they are steadily involved in formally organized Maker activities beyond the Maker Faire. Examples of organizations that the Makers are involved in include annual Maker events such as Burning Man, specialty technical groups and hobbyist/hack clubs, outreach organizations and competitions such as FIRST Robotics, and organizations that celebrate making such as Makerzine and Instructables. The Makers seek careers that align with or support their desire to Make and establish professional and personal support structures to fuel their Making. The Makers identify their jobs as engineering professionals, engineering graduate students, artists, 
engineering or art professors, hobbyists, or entrepreneurs. The Makers participate and seek interdisciplinary communities of learners to Make. One graduate student at a New York technical university program writes that her Making is supported by her academic community, which includes "a guy across the table that can help me with musical questions, down the hall is the guy that can help with my circuit, and I am a person that can help them." Whether the Makers are starting new ventures, Making within their structured job, or Making for recreation, they seek relationships with individuals of different backgrounds than themselves and have a value for knowledge.

\section{How do the Makers interact and engage in collective learning at the Maker Faires?}

The Makers' identity is defined by a commitment to Making and value for competence in Making. The Makers recognize that collaborating and sharing with others is pivotal to their Making and success as a Maker. The Maker Faire represents a place to express their belongingness and commitment to the Making community and a place to share resources, including their experiences, stories, tools, and problems. The specific ways in which the Makers interact and present at the Maker Faire is influenced by their professional goals, but transcending individual perceptions, Makers see the Maker Faire as a way to legitimize their work and to become a part of the community of Makers. One participant says, "Prior to the Maker Faire I was involved in community forums where you talk about things, electronics, audio, and that kind of stuff but [...] my official integration with the Maker movement was by going to the Maker Faire." Another participant says, "Well I've been going to the Maker Faire since they've been showing up in New York City so I think that's the third year straight now, and I've been looking for a way to participate really because I think that people here are great. I think they're nice and really wildly inventive. And I was just very happy to count myself among that crowd."

The Makers have different ways of interacting and engaging in collective learning at the Maker Faires. Emergent and overlapping themes are viewing the Maker Faire as: an art show for their technical artifact, a place to share their technical knowledge with other Makers and belong to a like-minded community, a place to get exposure for a new business or Kickstarter, and a place to see users interact with the technical artifact. Often these goals overlap.

Demonstrating her view of the Maker Faire as an art show, a freelance electronics engineer explains that she exhibits different technical artifacts at different Maker events. "I like to not exhibit the same piece over and over again. This particular piece had only been to burning man. It hadn't gone anywhere else." Often these pieces are used to showcase the Maker's latest developments and progress as a Maker. A robotics engineer explains that his artifacts are used to tell a story of progress and are to be shared with others. "It is a labor of love, it is more of a hobby than anything else. Well the engineering and art together and sharing it with other people." The Makers also value the Maker Faire as a way to keep their Making relevant and alive in the community. A craftsman showcases his hand-crafted wooden bicycles to "keep that craftsmanship alive." The Maker Faire supports Makers' desire to share technical knowledge. An entrepreneurial engineer explains that he wants to contribute to the technical community by sharing his knowledge and that the Maker Faire was a platform to interact with others who can learn from him and his artifact. "I didn't come up with the 3D printer idea, but I got into this via the open source 3D printer community. I started with that, and you know those printers are good but there are some downsides to them that I felt needed to be addressed." Makers also attend the Maker Faire to get exposure with like-minded individuals. An immigrant artist moved to the 
California area to share his interest in up-cycling technical equipment and to become known for his craft. "One day I want to be known for what I make." An engineering entrepreneur explains how he turned his interest in engineering and music into a business. "We are trying to get people to think of new uses for things they might throw away. It started when we were in college; we were musicians, played guitar. We needed up coming up with what is called the soda can guitar amplifier. I studied manufacturing engineering, so the study of how you make things. And I teamed up with by buddy who does electrical stuff and we put our skills together to invent soda can portable speaker." The Makers are showcasing their artifacts and seeking exposure. An engineering graduate student explains how her team is gaining traction with research and development of their printing technologies. "We like to think of ourselves as a boutique machine company, so we make all your other machines. So the machine we brought is the [printing machine]. [...] This is our R\&D department over here." Finally, Makers value the Maker Faire as a place where they can see the users interact with the artifact. A hobbyist explains that he brings his toys to the Maker Faire to see users interact with them. "I think the kind of participatory nature of Maker Faire fits very well with the [electronic toy] and, so far, it's been proven true. People have been very willing to use it and engage with it and ask questions about it. So we've had a great time." Often, the Makers interact with the users so that they can learn how to improve their products. An engineer explains that having users interact with the product during prototyping is beneficial. "We had been iterating for a while and I really wanted to put it in people's hands and see what they did with it."

These overlapping, emergent themes demonstrate some of the ways that the Makers interact and engage in collective learning. For the Makers, collective learning involves participating in joint activities, discussions with users and Makers, sharing information, and building relationships with Makers.

\section{Concluding Statements}

A more inclusive vision of engineering crossed with making could build future engineering capacity as well as raise awareness to the general public of the work and impact such work offers. Findings from the Center on the Advancement of Engineering Education's Academic Pathways Study ${ }^{16}$, studying undergraduate persistence in engineering and students' pathway by and through engineering studies, found two groups of students with different motivations for engagement. The first seeks financial security, overcoming barriers of foundational math and science courses to continue, aiming for graduation. The second approached their studies with an intrinsic psychological motivation, seeking meaning and impact through their studies. Our ambition is to change the conversation to highlight the efficacy and possibilities for this second group. We do not equate engineering students, practicing engineers and Makers completely but find the possible overlaps and stories of pathways within to be possible for transformational change in our field. Consider the benefits to STEM and resulting societal benefits for those who have influence over student decisions like teachers, school counselors, and parents to have an appreciation of the multiplicity of pathways into such careers or the value of technical literacy, both based in problem solving or making activities. This is especially true for underrepresented group to make the case that they are evident in the population of people already doing. 


\section{References}

1. Ethos. (n.d.). Merriam Webster Dictionary. Retrieved from http://www.merriamwebster.com/dictionary/ethos

2. MAKE. (n.d.). Retrieved April 7, 2013, from www.makezine.com.

3. Heile, 2006. (2006). Survival research labs. Ambidextrous Journal of Design: Endless Summer 2006, 2629. Retrieved February 10, 2012 from http://ambidextrousmag.org/issues/04/pdf/i4p27-29.pdf.

4. Yen, C. (2008). Lee Krasnow: A puzzling designer. Ambidextrous Journal of Design: Secret Winter 2008, 15-17. Retrieved February 10, 2012, from http://ambidextrousmag.org/issues/08/article.php?i8p15 17.

5. Brand, S. (1971). The last whole earth catalog: Access to tools. New York: Random House.

6. McFedries, P. (2007, June) The hobbyist renaissance. IEEE Spectrum.

7. Tech Shop (n.d.). Retrieved February 10, 2012, from http://techshop.ws.

8. Tweney, D. (2009, March 29). DIY freaks flock to 'hacker spaces' worldwide. Wired. Retrieved April 13, 2013 from http://www.wired.com/gadgetlab/2009/03/hackerspaces.

9. More than just digital quilting. (2011, December 3). The Economist. Retrieved April 7, 2013, from www.economist.com/node/21540392.

10. Honey, M., \& Siegel, E. (2010). Proceedings from the Innovation, Education \& Maker Movement Workshop. New York Hall of Science.

11. Wenger, E. (2010). Communities of practive and social learning systems: the career of a concept. In Blackmore, C. (Ed.) Social Learning Systems and Communities of Practice. Springer Verlag and the Open University.

12. Sheppard, S. D., Macatangay, K., Colby, A., \& Sullivan, W. M. (2008) Educating engineers: Designing for the future of the field. San Francisco: Jossey-Bass

13. National Academy of Engineering (2004). The Engineer of 2020: Visions of Engineering in the New Century. Washington, DC: The National Academies Press.

14. Jordan, S., Adams, R., Pawley, A., \& Radcliffe, D. (2009). WIP The affordances of photo elicitation as a research and pedagogical method. Frontiers in Education (FIE) Conference, San Antonio, TX.

15. Flanagan, J. (1954). The critical incident technique. Psychological Bulletin, 51, 327-58.

16. Atman, C. J., Sheppard, S. D., Turns, J., Adams, R. S., Fleming, L. N., Stevens, R., Streveler, R. A., Smith, K. A., Miller, R. L., Leifer, L. J., Yasuhara, K., \& Lund, D. (2010). Enabling engineering student success: The final report for the Center for the Advancement of Engineering Education. San Rafael, CA: Morgan \& Claypool Publishers. 